\title{
URANIUM, THORIUM, LEAD, LANTHANOIDS AND YTTRIUM IN SOME PLANTS GROWING ON GRANITIC AND RADIOACTIVE ROCKS
}

\author{
INKERI YLIRUOKANEN
}

\begin{abstract}
YLIRUOKANEN, INKERI 1975: Uranium, thorium, lead, lanthanoids and yttrium in some plants growing on granitic and radioactive rocks. Bull. Geol. Soc. Finland $47,71-78$.
\end{abstract}

\begin{abstract}
Spark source mass spectrometry with electrical detection was used for the determination of trace element contents in the ash of 172 plants comprising 21 lichens, 42 mosses, 78 dwarf shrubs and 31 trees.

The highest contents found in single samples were $2800 \mathrm{ppm} \mathrm{U}$ in one moss, $20 \mathrm{ppm} \mathrm{Th}$ in one moss and one lichen, 1200 to $1000 \mathrm{ppm} \mathrm{Pb}$ in lichens and mosses and in one Calluna vulgaris, 110 to $100 \mathrm{ppm} \mathrm{Y}$ and La in some lichens and mosses and $350 \mathrm{ppm} \mathrm{Ce}$ in one moss; the mean contents were usually significantly lower. No anomalies were found in the lanthanoid distribution in these plants and the influence of uranium and lanthanoid mineralizations was detectable only in the immediate vicinity of mineralized spots.
\end{abstract}

Inkeri Yliruokanen, Department of Chemistry, Helsinki University of Tecbnology, SF-02150 Espoo 15, Finland.

\section{Introduction}

The aim of this survey was to investigate the occurrence of uranium, thorium, lead, lanthanoids and yttrium in plants growing abundantly on granitic rocks in Finland. Only longer-living plants were sampled: conifers, deciduous trees, dwarf shrubs (Vaccinium sp. and Calluna vulgaris), mosses and lichens. The samples were taken from the same granites and deposits of $\mathrm{U}$, Th, and lanthanoids whose geology and analytical data were presented previously by Nie- minen and Yliruokanen (1974). In these regions the bedrock is often uncovered or the soil is very shallow, which showed make it feasible to study the influence of bedrock on the trace element content of the plants. One sample of each species was taken from normal granites, but at mineralized sites the sampling was more detailed in order to study the possible accumulation of these elements when their content in the substrate is higher and to investigate the influence of these anomalous contents on plants at small distances from the mineralizations. 


\section{Experimental}

Collection of samples: The samples were collected in the summer of 1972 from sites 2, 4, 5, 6, 7 and 8 , which are depicted in Fig. 1 of the previous report (Nieminen, Yliruokanen 1974). The samples taken from each site are presented in Table 1. The bulk of the samples was taken from Bodö (7) and Källdö (8), detailed maps of which are presented in Fig. 2 of the previous report. On Bodö a few samples could be taken from a sampling pit about 15 years old of pegmatite $7 / 2$; the other samples were taken at a distance of 2 to 100 metres from this pit $(7 / 2 \mathrm{a})$, at a distance of 1 to 2 metres from pegmatite $7 / 3$ and also on Långholmen $(7 / 5$ and $7 / 5 \mathrm{a})$. The mineralization in pegmatite is at the eastern end of this small island, which is situated about $1 \mathrm{~km}$ $\mathrm{E}$ of Bodö ( $c f$. Fig. 2 in the previous report). The mineralized pegmatite $(7 / 5)$ contains about 300 ppm Y, 1100 ppm La, 3000 ppm Ce, 250 ppm Pr, 1000 ppm Nd, 200 ppm Pb, 3300 ppm
Th and $1700 \mathrm{ppm}$ U. Only Calluna vulgaris was growing directly on the pegmatite $(7 / 5)$. The other samples were taken at a distance of 2 to 100 metres from this pegmatite $(7 / 5 \mathrm{a})$. On the island Källdö the first samples were taken at a distance of 1 to 10 metres from known uranium mineralizations $(8 / 3-7)$ and the background samples (8/7 a) 200 metres SE of pegmatite $8 / 7$. Furthermore, two systematic sampling lines (lines I and II in Fig. 2 in the previous report) were extended over mylonites $8 / 9$ and $8 / 8$. On line I sampling was started at the shore. On line II it was started at a distance of 1 metre from mylonite 8, three samples were taken SE of this point and four NW of it. The sampling points were 25 metres apart on both lines. Trees were not sampled, but all other plants were whenever possible.

The lichens and mosses from the Askola deposit have been studied earlier (Erämetsä, Yliruokanen $1971 \mathrm{a}, \mathrm{b}$ ), so this time only two samples of the Vaccinium species and Calluna vulgaris

TABle 1

The plants taken from the different sampling sites. The ash $\%$ is the arithmetic mean of ash as a percentage of dry matter

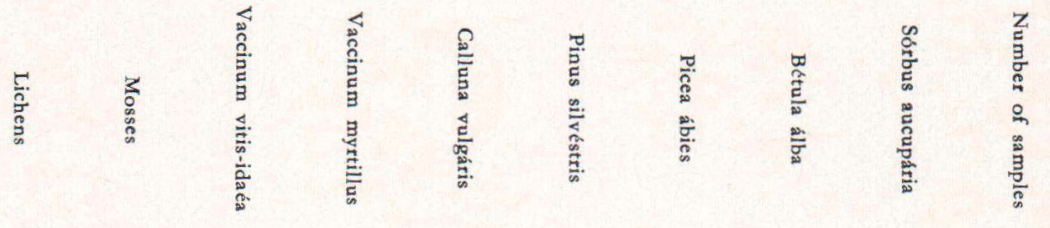

No. Site

\begin{tabular}{|c|c|c|c|c|c|c|c|c|c|c|c|}
\hline 2 & Onas $\ldots \ldots \ldots \ldots \ldots$ & 3 & 3 & 1 & 1 & 1 & - & - & - & - & 10 \\
\hline 4 & Kuivasaari .......... & 2 & 2 & 1 & 1 & 1 & 1 & 1 & 1 & 1 & 11 \\
\hline 5 & Käärmesaari ........ & $\overline{1}$ & 2 & 1 & 1 & 1 & 1 & 1 & 1 & - & 9 \\
\hline 6 & Askola .............. & - & - & 1 & 1 & 1 & - & - & - & - & 3 \\
\hline 7 & Bodö 2 a ........... & 3 & 4 & - & 1 & 2 & 2 & - & - & - & 12 \\
\hline 7 & Bodö $2 \ldots \ldots \ldots \ldots$ & - & 1 & 1 & 1 & 1 & - & - & - & - & 4 \\
\hline 7 & Bodö 3 a $\ldots \ldots \ldots \ldots$ & 1 & 1 & 1 & - & 1 & - & - & - & - & 4 \\
\hline 7 & Bodö 5 a ............ & 1 & 5 & 1 & 1 & 2 & 2 & - & 2 & - & 14 \\
\hline 1 & Bodö $5 \ldots \ldots \ldots$ & - & - & - & - & 1 & - & - & - & - & 1 \\
\hline 8 & Källdö $3-7$ a ........ & - & - & 1 & 1 & - & 1 & 1 & 1 & 1 & 6 \\
\hline 8 & Källdö $3-7 \ldots \ldots \ldots$ & 5 & 5 & 2 & 3 & 3 & 4 & 3 & 4 & 2 & 31 \\
\hline 8 & Källdö I .......... & 3 & 12 & 13 & 13 & - & - & - & - & - & 41 \\
\hline & Källdö II $\ldots \ldots \ldots \ldots$ & 2 & 7 & 7 & 8 & 2 & - & - & - & - & 26 \\
\hline & mber of samples. & 21 & 42 & 30 & 32 & 16 & 11 & 6 & 10 & 6 & 172 \\
\hline & $\mathrm{h} \%$ (mean) .......... & 1.9 & 5.2 & 3.2 & 4.2 & 3.4 & 2.3 & 3.4 & 3.9 & 6.2 & - \\
\hline
\end{tabular}



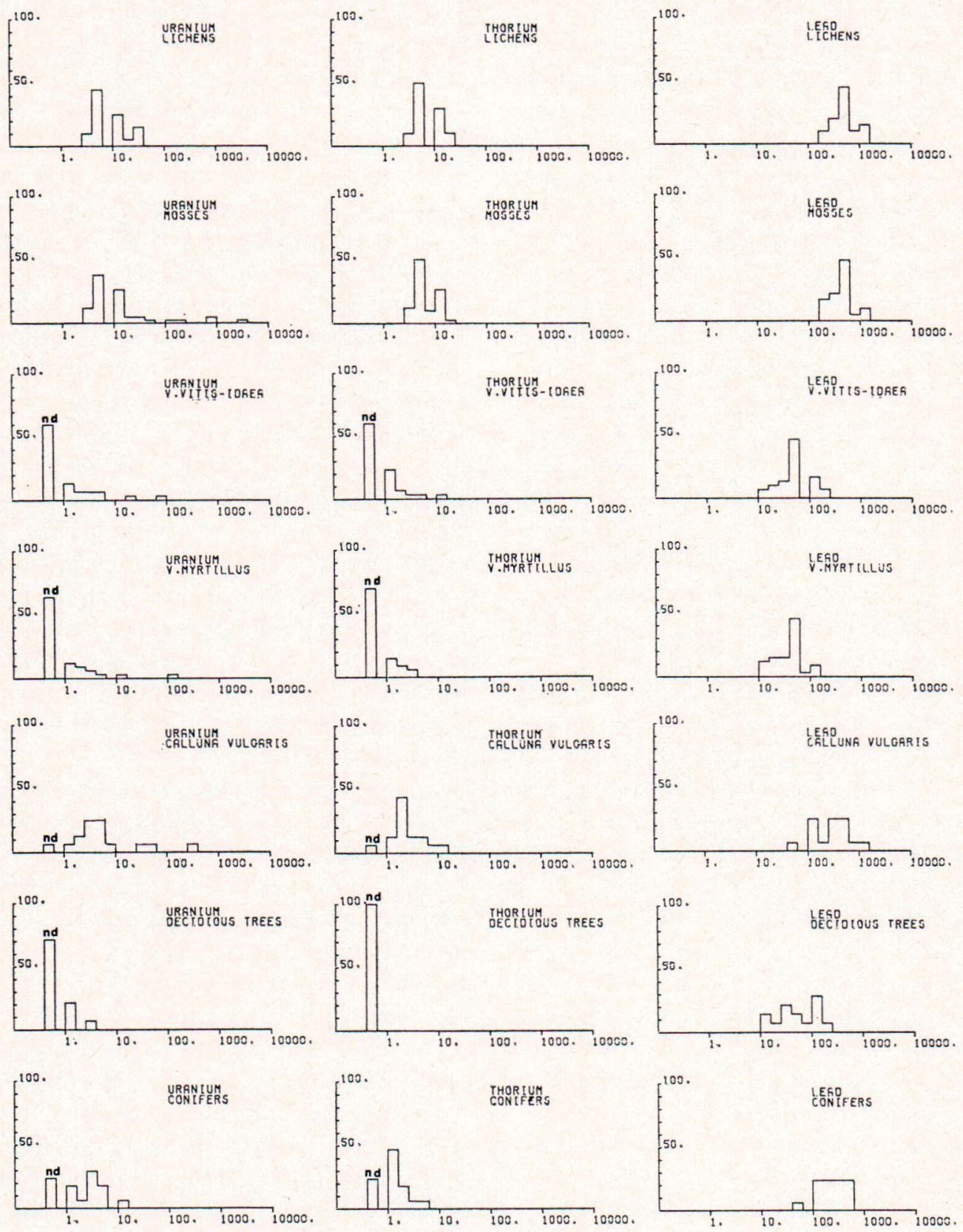

Fig. 1. Frequency (\%) histograms of uranium, thorium and lead contents (ppm) in ash of different plants. The number of samples was lichens 21, mosses 42, Vaccinum vitis-idaea 30, V. myrtillus 32 , Calluna vulgaris 16 , decidious trees 14 , conifers 17 . The samples whose content was below detection limit are indicated by $» n d)$. 
were taken at a distance of 5 metres to south from pegmatite 6/2. From unaltered granites (sites 2, 4 and 5) only one sample of each tree and dwarf shrub species was taken. From lichens and mosses 1 to 3 species were sampled. The lichens and mosses were collected and purified as described earlier (Erämetsä, Yliruokanen 1971 a). In previous studies no significant differences were obtained between the trace elements determined in different species of these plants. For this study the following species were selected for sampling: Cladonia alpestris (10 samples), Cl. arbuscula (8 samples), Cetraria islandica (2 samples), Pleurozium Schreberi (22 samples), Sphagnum sp. (10 samples), Hylocomium splendens (4 samples), Dicranum sp. (4 samples), Polytrichum commune (1 sample) and Rhacomitrium microcarpon (1 sample). The Vaccinium and Calluna samples were taken without roots. Small twigs with needles or leaves were taken from the trees. The youngest shoots were removed.

Preparation of samples: The samples were ashed as described earlier (Erämetsä, Yliruokanen 1971 a). The maximum temperature was $550^{\circ} \mathrm{C}$. The mean ash percentage for each plant group is presented in Table 1. The electrodes for the mass spectrometric analysis were made from a mixture of $100 \mathrm{mg}$ plant ash and $100 \mathrm{mg}$ pure graphite (Ringsdorff RW A) by the usual polythene slug technique.

The analytical method: Spark source mass spectrometry with electrical detection was used. Synthetic standards were scanned alternately with the samples and the results were calculated by comparing standards and samples (Erämetsä et al. 1973). The detection limit was 0.3 to $4 \mathrm{ppm}$. The precision was better than $\pm 20 \%$ (Nieminen, Yliruokanen 1974).

\section{Results and discussion}

The uranium, thorium and lead contents in different plants are depicted in Fig. 1.
Uranium: The highest content in lichens was $30 \mathrm{ppm}$ in the ash of three samples from Bodö and Källdö, where the U content of granite was $17 \mathrm{ppm}$, and from Kuivasaari, where the U content of granite was only 4 ppm.

The $U$ content was higher in some mosses and dwarf shrubs growing directly on mineralized pegmatites $(7 / 2$ and $7 / 5)$ or very close to mylonites ( $8 / 3$ and $8 / 4)$. The contents of $U$ in plants and rocks are presented in Table 2. Both Sphagnum samples were growing in water that was in direct contact with the mylonites, but whose $\mathrm{U}$ content was only about $2 \mathrm{ppm}$. In addition to these mosses, a $U$ content of 900 ppm was found in Rhacomitrium microcarpon and $100 \mathrm{ppm}$ in Hylocomium splendens, both of which were growing quite near pegmatite $7 / 5$. The U content in the lichens from lines $8 / \mathrm{I}$ and $8 / \mathrm{II}$ was 3 to $10 \mathrm{ppm}$, in mosses 3 to $15 \mathrm{ppm}$, in Vaccinium vitis-idaea $1.5 \mathrm{ppm}$ (in 5 samples) and in $V$. myrtillus $1.3 \mathrm{ppm}$ (in 4 samples). Obviously in this kind of environment the influence of uranium mineralization is noticeable only at very short distances.

In twigs of decidious trees uranium could only be detected in three Betula alba samples from Bodö and Källdö; the content was 1 to $3 \mathrm{ppm}$. In twigs of conifers the highest content (15 ppm) was in a spruce growing quite near mylonite $8 / 3$; in three pines near mylonites $8 / 3$ and $8 / 4$ and pegmatite $7 / 2$ it was $5 \mathrm{ppm}$, and in conifers from Kuivasaari it was $1.3 \mathrm{ppm}$.

Cannon (1960) considers that about $1 \mathrm{ppm}$ uranium in ash is anomalous in conifers. According to Dean (1966), the median U content in ashed pine needles in Great Britain is 0.68 ppm. From Alaska Eakins (1970) has reported an uranium content of $2396 \mathrm{ppm}$ in the ashed twigs of lodgepole pine.

The uranium content is lower in twigs than in roots; Cannon (1960) has reported a ratio of 2200 for the $U$ content in roots and twigs of Juniperus monosperma. In this work a spruce about 10 years old growing in an old mylonite ore pile $8 / 3$ was investigated. Its $U$ content (in ash) was 
TABLE 2

Uranium and thorium (ppm) in rock samples and plant ash

\begin{tabular}{|c|c|c|c|c|c|c|c|c|c|}
\hline \multirow[b]{2}{*}{ Rock } & \multirow[b]{2}{*}{ U ppm } & \multirow[b]{2}{*}{ Th ppm } & \multicolumn{2}{|c|}{ Mosses } & \multicolumn{2}{|c|}{ V. vitis-idaea } & v. myrtillus & \multicolumn{2}{|c|}{ Calluna vulgaris } \\
\hline & & & $\mathrm{U}$ & $\mathrm{Th}$ & $\mathrm{U}$ & Th & $\mathrm{U}$ & $\mathrm{U}$ & Th \\
\hline $7 / 2$ & 560 & 790 & $160+$ & 6 & 90 & 10 & 150 & 30 & 3 \\
\hline $7 / 5$ & 1700 & 3300 & - & - & - & - & - & 270 & 8 \\
\hline $8 / 3$ & 1100 & 50 & $900 *$ & 6 & - & - & 3 & - & - \\
\hline $8 / 4$ & 1000 & 30 & $2800^{*}$ & 10 & - & - & - & 60 & 2 \\
\hline
\end{tabular}

+) Polytrichum commune, *) Sphagnum

$700 \mathrm{ppm}$ in the roots, $50 \mathrm{ppm}$ in the stem, 80 ppm in the twigs and $16 \mathrm{ppm}$ in the youngest shoots.

Thorium: As expected the content was low in all samples, because thorium minerals are very stable and the mobility of thorium is low. In lichens and mosses the thorium content was 3 to $20 \mathrm{ppm}$; the highest contents were obtained in samples from Käärmesaari, Kuivasaari and Bodö. In Vaccinium sp. the highest contents were in the same samples as were the highest uranium contents (cf. Table 2). In Calluna vulgaris the highest content $(12 \mathrm{ppm})$ was in a sample from Onas where the granite contains only $18 \mathrm{ppm}$ Th. In decidious trees the thorium content was below detection limit in all samples. In conifers the highest contents ( 3 to $5 \mathrm{ppm}$ ) were found in pine samples from Bodö.

Lead: The content in lichens was 200 to 1200 ppm, in mosses 200 to $1000 \mathrm{ppm}$ and in Calluna vulgaris 50 to $1000 \mathrm{ppm}$. The highest contents were in samples from Kuivasaari, Onas and Bodö; the lowest contents were in samples from Källdö.

Lower contents were obtained in Vaccinium sp. and in the trees. In Vaccinium vitis-idaea 10 to $200 \mathrm{ppm}$ was found; the highest contents were in samples from Kuivasaari, Onas and Källdö. In $V$. myrtillus the range was 10 to $100 \mathrm{ppm}$, the highest content was in samples from Kuivasaari and Källdö. In decidious trees the $\mathrm{Pb}$ content was 150 to $200 \mathrm{ppm}$ in samples from Kuivasaari, Käärmesaari and Onas and 10 to $100 \mathrm{ppm}$ in samples from Källdö.

In conifers the $\mathrm{Pb}$ content was $50 \mathrm{ppm}$ in one spruce from Källdö and 100 to $400 \mathrm{ppm}$ in the other samples from Källdö. In the other samples the abundance was 200 to $600 \mathrm{ppm}$.

In several rock samples the isotopic abundances of lead were influenced by radiogenic lead (Nieminen and Yliruokanen, 1974). This phenomenon could not be seen in plant samples, possibly owing to the high lead content in plant ash.

Yttrium and lanthanoids: The $\mathrm{Y}, \mathrm{La}$ and $\mathrm{Ce}$ contents in different plants are depicted in Fig. 2. The range and median values for all the lanthanoids are presented in Table 3. No anomalous lanthanoid distribution was found in these plants. The contents were higher in lichens, mosses and Calluna vulgaris than in the other plants. The highest contents in Vaccinium sp. were in the same samples in which the highest uranium contents in these plants were found. The plants were growing on pegmatite $7 / 2$, which contained 860 ppm Y, 450 ppm La and 900 ppm Ce. The results are in good agreement with the $\mathrm{Y}$ contents reported by Lounamaa (1956) for different plants as well as with the yttrium and lanthanoid contents in bryophytes reported by Shacklette (1965). Shacklette stated that bryophytes can concentrate rare earths even when they grow on substrates in which these elements have not been detected. In the present study a similar observation was made for europium in samples from Bodö, where the Eu content of all the rock 

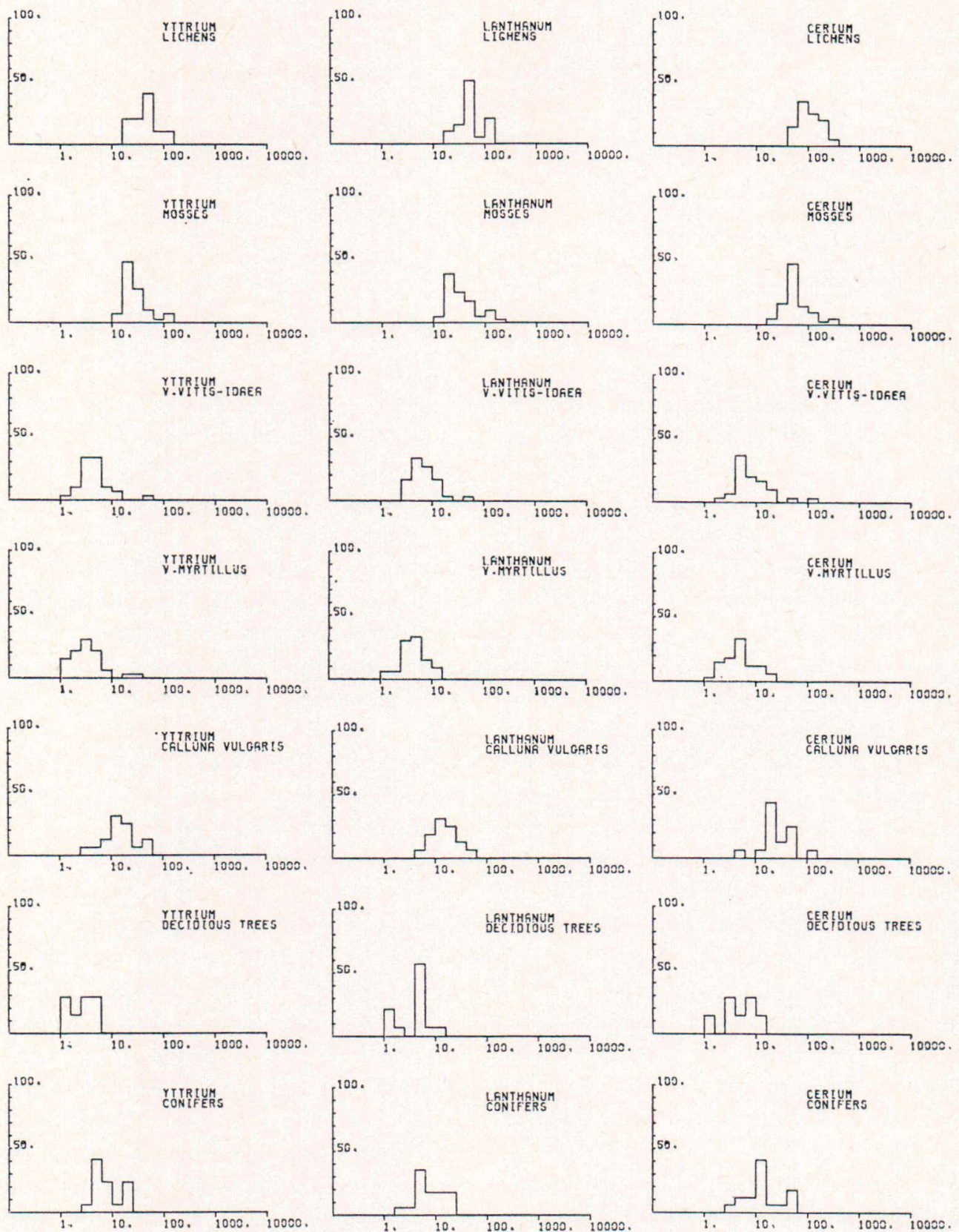

Fig. 2. Frequency (\%) histograms of yttrium, lanthanum and cerium contents (ppm) in ash of different plants. The number of samples is the same as in Fig. 1. 
TABLE 3

Median and range of yttrium and lanthanoid contents in plant as (ppm). The number of samples in each plant group is given in brackets. $\mathrm{N}$ is the number of samples in which the content was above detection limit

\begin{tabular}{|c|c|c|c|c|c|c|c|c|c|c|c|c|}
\hline & Liche & s (21) & & Mosse & (42) & & V. vitis-ic & ea (30) & & V. myrti & lus (32) & \\
\hline & median & range & $\mathrm{N}$ & median & range & $\mathrm{N}$ & median & range & $\mathrm{N}$ & median & range & $\mathrm{N}$ \\
\hline$Y \ldots$ & 40 & $23-100$ & 21 & 25 & $10-100$ & 42 & 3.0 & $1.0-60$ & 30 & 3.0 & $1.2-50$ & 32 \\
\hline La ... & 45 & $25-120$ & 21 & 25 & $14-250$ & 42 & 7.0 & $2.6-50$ & 30 & 4.0 & $1.0-12$ & 32 \\
\hline $\mathrm{Ce} \ldots$ & 90 & $43-260$ & 21 & 50 & $22-350$ & 42 & 7.0 & $2.0-140$ & 30 & 5.0 & $1.0-24$ & 32 \\
\hline $\operatorname{Pr} \ldots$ & 11 & $3.6-30$ & 21 & 6.0 & $3.0-45$ & 42 & 1.2 & $1.0-6.0$ & 24 & 1.2 & $1.0-5.0$ & 21 \\
\hline $\mathrm{Nd} \ldots$ & 40 & $16-200$ & 21 & 25 & $10-200$ & 42 & 7.0 & $3.0-50$ & 16 & 6.0 & $4.0-18$ & 11 \\
\hline $\mathrm{Sm} \ldots$ & 10 & $5.0-35$ & 21 & 6.0 & $3.0-60$ & 39 & 4.0 & $3.0-14$ & 7 & - & 3.0 & 1 \\
\hline Eu ... & 3.0 & $1.0-5.0$ & 21 & 1.0 & $1.0-11$ & 36 & 1.0 & $1.0-5.0$ & 7 & - & - & - \\
\hline Gd .. & 9.0 & $5.0-50$ & 21 & 6.0 & $3.0-40$ & 36 & 4.0 & $3.0-10$ & 5 & - & 5.0 & 1 \\
\hline Tb... & 1.0 & $0.5-3.0$ & 20 & 1.0 & $0.5-4.0$ & 31 & 1.0 & $0.6-1.0$ & 5 & - & 1.0 & 1 \\
\hline Dy ... & 8.0 & $3.0-30$ & 20 & 6.0 & $3.0-60$ & 34 & 5.0 & $4.0-6.0$ & 3 & - & 5.0 & 1 \\
\hline Ho .. & 1.0 & $0.5-4.0$ & 20 & 1.0 & $0.5-4.0$ & 31 & - & - & - & - & 1.0 & 1 \\
\hline Er ... & 4.0 & $2.0-15$ & 19 & 3.0 & $2.0-17$ & 26 & - & - & - & - & 3.0 & 1 \\
\hline $\operatorname{Tm} \ldots$ & 1.0 & $0.4-3.0$ & 13 & 0.8 & $0.3-2.0$ & 18 & - & - & - & - & - & - \\
\hline $\mathrm{Yb} \ldots$ & 3.0 & $2.0-10$ & 17 & 3.0 & $2.0-12$ & 20 & - & - & - & - & 3.0 & 1 \\
\hline Lu ... & 1.0 & $0.3-2.0$ & 11 & 0.9 & $0.5-2.0$ & 12 & - & - & - & - & - & - \\
\hline
\end{tabular}

Table 3 cont.

\begin{tabular}{|c|c|c|c|c|c|c|c|c|c|}
\hline \multirow[b]{3}{*}{$Y \ldots$} & \multicolumn{3}{|c|}{ Calluna vulgaris (16) } & \multicolumn{2}{|c|}{ Decidious trees (14) } & \multicolumn{3}{|c|}{ Conifers (17) } & \multirow[b]{2}{*}{$\mathrm{N}$} \\
\hline & median & range & $\mathrm{N}$ & & range & $\mathrm{N}$ & & range & \\
\hline & 13 & $3.0-50$ & 16 & 3.0 & $1.0-5.0$ & 14 & 8.0 & $3.0-25$ & 17 \\
\hline $\mathrm{La} \ldots$ & 14 & $6.0-70$ & 16 & 5.0 & $1.0-10$ & 14 & 8.0 & $2.0-25$ & 17 \\
\hline $\mathrm{Ce} \ldots$ & 24 & $5.0-150$ & 16 & 5.0 & $1.0-10$ & 14 & 13 & $3.0-50$ & 17 \\
\hline $\operatorname{Pr} \ldots$ & 4.0 & $2.0-17$ & 16 & 1.5 & $1.0-2.0$ & 6 & 2.0 & $1.0-7.0$ & 17 \\
\hline Nd .. & 20 & $8.0-70$ & 16 & 5.0 & $4.0-10$ & 8 & 10 & $5.0-35$ & 14 \\
\hline $\mathrm{Sm} \quad \ldots$ & 6.0 & $3.0-12$ & 12 & 3.0 & $3.0-4.0$ & 3 & 5.0 & $3.0-8.0$ & 7 \\
\hline Eu ... & 1.0 & $1.0-3.0$ & 10 & - & - & - & 1.0 & $1.0-2.0$ & 5 \\
\hline Gd .. & 5.0 & $3.0-20$ & 10 & - & - & - & 5.0 & $3.0-8.0$ & 4 \\
\hline $\mathrm{Tb} \ldots$ & 1.0 & $1.0-2.0$ & 9 & - & - & - & - & 0.7 & 1 \\
\hline Dy ... & 4.0 & $3.0-12$ & 9 & - & - & - & 4.0 & $2.0-6.0$ & 4 \\
\hline Ho .. & 1.0 & $0.5-2.0$ & 8 & - & - & - & 1.0 & $1.0-2.0$ & 3 \\
\hline Er $\ldots$ & 3.0 & $2.0-4.0$ & 8 & - & - & - & 3.0 & $2.0-4.0$ & 3 \\
\hline $\mathrm{Tm}$ & 0.8 & $0.6-1.0$ & 4 & - & - & - & - & - & - \\
\hline $\mathrm{Yb} \ldots$ & 3.0 & $2.0-4.0$ & 6 & - & - & - & 2.0 & $2.0-3.0$ & 3 \\
\hline $\mathrm{Lu} \ldots$ & 0.9 & $0.7-1.0$ & 3 & - & - & - & 一 & - & 一 \\
\hline
\end{tabular}

samples except $7 / 3$ was below detection limit; in all mosses the Eu content was 1 to $4 \mathrm{ppm}$, in all lichens 1 to $5 \mathrm{ppm}$ and even in five of the seven Calluna samples 1 to $3 \mathrm{ppm}$. The variation in the lanthanoid content was quite large even in the same species taken from a limited area. On Källdö sampling line I traversed a rather well-known rock with uniform $\mathrm{Y}$ and lanthanoid contents. At each sampling point the plants were growing quite close to each other and were of roughly the same age. The rather large standard deviations of the means of contents can be seen in Table 4.

The relationship of the lanthanoid content in plant ash to that in rock samples was studied by statistical methods, but no significant correlation was found. This may be due to the fact that too few samples were taken from bedrock that is more or less heterogenous at the sampling sites. 
TABLE 4

Yttrium and lanthanoids (ppm) in plant ash and corresponding rocks $(8 / 2,8 / 9$ and $8 / 10)$ from Källdö I.

$\mathrm{N}$ is the number of samples in which the content was detectable

\begin{tabular}{|c|c|c|c|c|c|c|c|}
\hline & $\begin{array}{l}\text { Rocks } \\
\text { range }\end{array}$ & $\begin{array}{l}\text { Mosses } \\
\text { mean }\end{array}$ & $\mathrm{N}$ & $\begin{array}{l}\text { V. vitis } \\
\text { mean }\end{array}$ & $\mathrm{N}$ & $\begin{array}{l}\text { V. myrti } \\
\text { mean }\end{array}$ & $\mathrm{N}$ \\
\hline$Y \ldots$. & $20-50$ & $24.2 \pm 7.3$ & 12 & $4.0 \pm 2.0$ & 13 & $3.0 \pm 2.0$ & 13 \\
\hline La ... & $26-80$ & $23.2 \pm 10$ & 12 & $5.1 \pm 2.2$ & 13 & $3.7 \pm 1.5$ & 13 \\
\hline $\mathrm{Ce} \ldots$ & $60-115$ & $40 \pm 15$ & 12 & $6.0 \pm 3.9$ & 13 & $4.3 \pm 0.3$ & 13 \\
\hline $\operatorname{Pr} \ldots$ & $11-30$ & $5.4 \pm 2.5$ & 12 & $1.8 \pm 1.9$ & 12 & $1.5 \pm 1.0$ & 8 \\
\hline Nd .. & $45-70$ & $24.4 \pm 10$ & 12 & $5.7 \pm 4.1$ & 13 & $4.5 \pm 3.9$ & 12 \\
\hline $\mathrm{Sm} \ldots$ & $5.1-11$ & $4.5 \pm 1.7$ & 12 & 3.5 & 1 & - & - \\
\hline Eu ... & $1.0-2.8$ & $1.2 \pm 0.3$ & 10 & 1.0 & 1 & - & - \\
\hline Gd .. & $3.9-5.5$ & $4.5 \pm 2.0$ & 12 & 4.0 & 1 & - & - \\
\hline $\mathrm{Tb} \ldots$ & $1.6-2.0$ & $1.1 \pm 0.5$ & 9 & - & - & - & - \\
\hline Dy ... & $2.0-3.0$ & $4.4 \pm 1.5$ & 10 & - & - & - & - \\
\hline Ho .. & $0.5-0.6$ & $0.9 \pm 0.3$ & 6 & - & - & - & - \\
\hline Er ... & $1.1-3.0$ & $2.7 \pm 0.7$ & 5 & - & - & - & - \\
\hline $\operatorname{Tm} \ldots$ & 0.4 & $0.5 \pm 0.2$ & 3 & - & - & - & - \\
\hline $\mathrm{Yb} \ldots$ & 1.5 & $4.0 \pm 1.0$ & 3 & - & - & - & - \\
\hline
\end{tabular}

\section{Conclusions}

The influence of the trace element content of bedrock on different plants was obvious in only a few cases when the plants were growing directly on mineralized spots of uranium and lanthanoids; anomalous contents were found in mosses, Calluna vulgaris and Vaccinium sp. The thorium content was always low and mineralizations had no significant effect. The lead content was usually of about the same magnitude in each plant group. However, in Pernaja, Källdö, where the lead content of the rock samples was often higher than it was at the other sampling sites, the lead content in trees, mosses, lichens and Calluna vulgaris was lower than in the same plants taken from other sites. The influence of traffic lead is probably smaller at this site. The contents of the trace elements determined were slightly higher in lichens and mosses than in Calluna vulgaris. Lowest contents were generally found in Vaccinium sp. and in twigs of trees.

Acknowledgements - The author wishes to thank Mr. Aimo Viento and Mr. Kauko Matinmäki for their aid in sample collecting. Financial assistance from the Neste Oy Foundation is gratefylly acknowledged.

\section{REFERENCES}

Cannon, H. L. (1960) The development of botanical methods of prospecting for uranium on the Colorado Plateau. U. S. Geol. Surv. Bull. 1085-A. 50 p.

DEAN, M. H. (1966) A survey of the uranium content of vegetation in Great Britain. J. Ecol. 54: 589-595.

EAkıNs, G. R. (1970) An experiment in geobotanical prospecting for uranium, Bokan Mountain area, Southeastern Alaska. Div. Mines Geol. Rep. 41.52 p.

Erämetsä, O., HaArala, A-R., and Yliruokanen, I. (1973) Lanthanoid content in three species of Equisetum. Suom. Kemistilehti B 46: 234-236.

Erämetsä, O. and Yliruokanen, I. (1971a) The rare earths in lichens and mosses. Suom. Kemistilehti B 44: $121-128$.

Erämetsä, O. and Yliruokanen, I. (1971b) Niobium, molybdenum, hafnium, tungsten, thorium and uranium in lichens and mosses. Suom. Kemistilehti B 44: $372-374$.

LounamaA, J. (1956) Trace elements in plants growing wild on different rocks in Finland. Ann. Bot. Soc. „Vanamo» 29. 4. 196 p.

Nieminen, K. and Yliruokanen, I. (1974) Trace element analysis of granitic and radioactive rocks by spark source mass spectrometry with electrical detection. Bull. Geol. Soc. Finland 46: 169-178.

Shacklette, H. T. (1965) Element content of bryophytes. U. S. Geol. Surv. Bull. 1198-D. 21 p.

Manuscript received, December 12, 1974. 